\title{
MAMMALS
}

\section{SQUIRREL TAILS TIED IN KNOTS}

\author{
GARY HOIUM, Box 626, Weyburn, SK S4H 2K7
}

As an avid hockey fan and former player, I was sitting in my basement in Weyburn one evening in May 2003 watching a NHL playoff game when the phone rang. Some 19 years of rural veterinary practice had taught me to expect emergency calls at such times, but I was at a loss for words when the three anxious gentlemen on the line asked me to come over right away to a nearby seniors complex to solve a squirrel problem. A mass of squirrels with their tails tied together had been spotted, and the pensioners had been watching the octopus-like, grey furry formation moving erratically around the back lawn and parking area. Something had to be done! I paused and sniffed the phone receiver for alcohol. None! So we were all sober. Was this for real? "Maybe you should call the humane society," I responded hopefully, "I think they do squirrels after hours." The gentlemen quickly informed me that the police and the humane society had already been consulted and had voted unanimously that I be called. "Can't you just grab hold of them and pull them apart?" I asked. "Oh no way," they replied, "we tried; they scream and try to bite."

I called to my wife, "Shelley, we're going on a squirrel call." When we untangling. arrived, spectators were crowded behind every window. And there it was, a quartet of nearly-grown squirrels solidly joined by their tails and each pulling in a different direction. The squirrels were grey on the back and sides, with yellow-tan bellies, cheeks, chins and highlights on the back sides of the ears and on the feet, all indications that these were Eastern Fox Squirrels, although Eastern

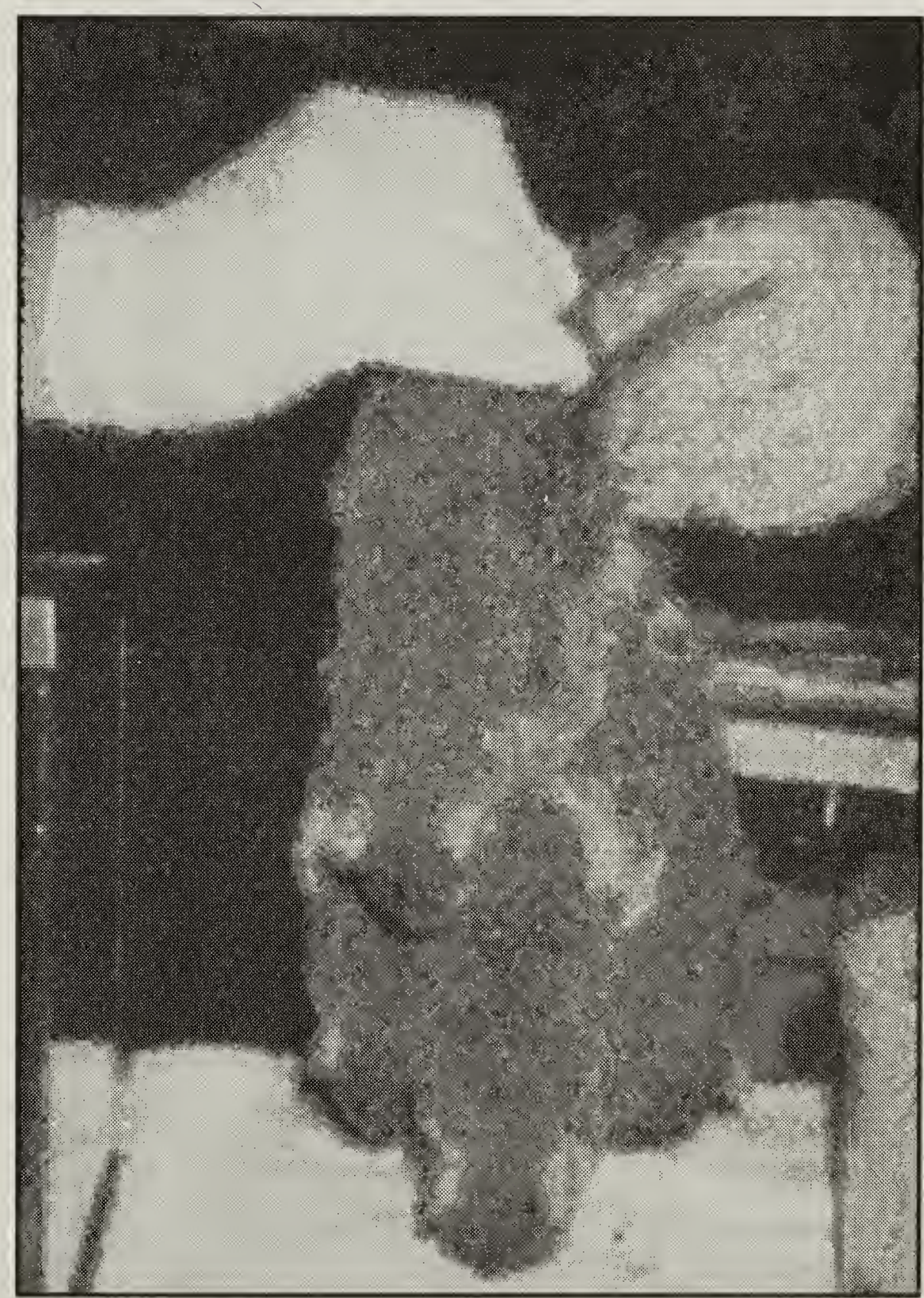

Figure 1. The four young Eastern Fox Squirrels with their tails tied together, anaesthetized and ready for

Gary Hoium 
Grey Squirrels also occur in the area and the two species are not easily distinguished. As I approached, the retreating formation got hooked on a short rose bush and I captured it with an overturned cardboard box. We transferred the angry, sore and frightened squirrels to a firmer container and returned to my clinic, very proud "first responders". Anaesthetic gas soon had the squirrels quiet and motionless. I removed them from the chamber and, as the squirrels hung from their entanglement, they reminded me of a chain of freshly-caught perch (Fig 1). "Time for a bath, boys and girls."

It took less than 5 minutes to successfully untangle and separate the squirrels. The tails were so entangled, it was as if someone had literally taken these squirrels and tied their tails together the way we would tie our shoes. Dried, crusted faecal matter and debris served to cement and reinforce this intimate relationship of tails. After soaking and dissolving and picking off the solidified organic matter from this mass, I still had to forcefully untie three or four real knots. Indeed, after separation, all the tails appeared disjointed and misaligned, suggesting dislocation and/or fracture of some of the tail vertebrae. Thus there may have been some permanent damage to the tails. Had the tangled squirrels been left to fend for themselves, it seems likely that the tail tissue would have died, if the squirrels did not die first, and some tail-less young squirrels would have been the result.

By the time the washing and disentanglement was complete, it was dark and cold outside, so I decided to let the squirrels wake up and recover in a large portable dog kennel in the warmth of my heated garage. Release was scheduled for 7:45 a.m. the next morning, back at the capture site. Despite the hour, a large audience was again assembled behind the lawn-facing windows. I located a grassy spot adjacent to the building and poured the squirrels out onto the lawn. They literally hit the ground running, each in a different direction and this time successfully! Mission accomplished.

Although I fully believe this was a natural phenomenon, initially I might easily have been convinced that it was a practical joke. My theory as to why and how tails become entangled and knotted in this way is that some sticky substance like tree sap or loose stool first coats the tails and glues them together as the squirrels cuddle in the nest. The glue holds the tails together as the squirrels move around each other, and knotted tails are the result. Further strengthening the bond is additional faecal matter inevitably deposited on the joined tails. A resident at the seniors' complex had a different theory: "The mother squirrel ties them together like that when the babies get older so she can keep track of them all when they escape their nest."

I have since learned that squirrels with their tails stuck and tied together have been seen elsewhere. Doug Campbell of the Canadian Cooperative Wildlife Health Centre at the Ontario Veterinary College once received a cluster of eight Eastern Gray Squirrels in this condition, all of them found dead in a cemetery in Toronto (Fig 2). Young Norway Rats also are reported to develop tangled, knotted tails. Doug Campbell reports that, upon seeing the photo shown here as Fig 2, a gentleman in Erin, Ontario told him that he had seen the same thing in rats in Holland. He said it was a well-known phenomenon, and was called a "king of rats." His point is strengthened by the following quotation:

"Surely there are many stories of rat cooperation and even compassion. A good example is the famous Rattenkonig or 'rat king'. Young rats close to one another in the nest sometimes get their tails entangled and become a living Gordian knot glued together by dirt encrusted wounds and the like. When they try to pull apart the tails are pulled 




Figure 2. Eight Eastern Grey Squirrels with their tails entangled and tied together. These tangled squirrels were found dead near Toronto, ON. Both grey and black colour variants are present in the group.

Doug Campbell

tight, and the knots strengthen, knitting the rats together. As many as 32 rats are trapped in these knots and have died as a result of being unable to forage for themselves. However, they are often unselfishly fed for life by other family members." '

1. HENDRICKSON, R. 1999. More Cunning than Man: A Social History of Rats and Men; Dorset Press, New York; pp. 92 - 93.

[Editors' Note: During the editorial process for this interesting article, it became evident that the accidental knotting of tails is well known to persons who offer medical care to injured wildlife and who live within the range of the Eastern Grey Squirrel. Sandie Black of the Calgary Zoo reports that the zoo received and treated six such knots of Eastern Grey Squirrels between 1987 and 1993, a period during which the zoo's veterinary staff accepted wild animals for treatment. Three cases consisted of foursquirrel knots, two of five squirrels, and one of six squirrels. In several cases, the tails were severely damaged and required amputation. Numerous Internet web sites also document this phenomenon; some even give instructions for disentangling the squirrels. All explanations offered for this phenomenon conform to the hypothesis proposed above by Gary Hoium. We encountered no information about other instances involving fox squirrels. - Editors ]

"The squirrel is a tiny animal that is very easily angered. It is said that because of their nature squirrels often die of blind rage."

A Cloisters Bestiary, p 14 (compiled from medieval texts) 